\title{
Loss of S100A14 Expression Is Associated with the Progression of Adenocarcinomas of the Small Intestine
}

\author{
Gwangil Kim $^{a}$ Joon-Yong Chung ${ }^{b}$ Sun-Young Jun ${ }^{c}$ Dae Woon Eom ${ }^{d}$ \\ Young Kyung Bae $^{\mathrm{e}}$ Kee-Taek Jang ${ }^{f}$ Jihun Kim ${ }^{g}$ Eunsil Yu ${ }^{g}$ Seung-Mo Hong ${ }^{g}$ \\ a Department of Pathology, Bundang CHA Medical Center, CHA University, Seongnam, Korea; ${ }^{\mathrm{b}}$ Applied Molecular \\ Laboratory and Tissue Array Research Program, Laboratory of Pathology, National Cancer Institute, National

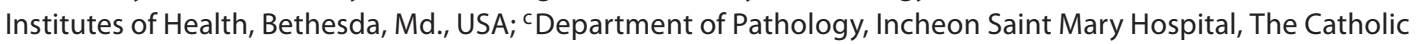 \\ University of Korea College of Medicine, Incheon, ${ }^{\mathrm{d} D e p a r t m e n t}$ of Pathology, Gangneung Asan Hospital, University \\ of Ulsan College of Medicine, Gangneung, e Department of Pathology, Yeungnam University College of Medicine, \\ Daegu, fDepartment of Pathology, Samsung Medical Center, Sungkyunkwan University School of Medicine, Seoul, \\ and ${ }^{9}$ Department of Pathology, Asan Medical Center, University of Ulsan College of Medicine, Seoul, Korea
}

\section{Key Words}

Adenocarcinoma $\cdot$ p21 $\cdot$ p53 $\cdot$ S100A14 $\cdot$ Small intestine

\begin{abstract}
Objectives: Small intestinal adenocarcinoma (SIAC) is an exceedingly rare human malignant tumor, and its association with the S100A14 gene is not known yet. We aimed to investigate the clinicopathological correlations between S100A14 expression and SIAC. Methods: Immunohistochemical analyses of S100A14, p21 and p53 were performed using tissue microarray analysis of 175 surgically resected SIACs. Results: Of 175 SIACs, loss of S100A14 expression was observed in 128 cases $(73.1 \%)$. Loss of S100A14 expression was associated with lymph node metastasis $(p=0.009)$ and advanced disease stage $(p=0.013)$, and was more frequently observed in distal than duodenal tumors $(p=0.043)$. The majority of SIACs lost p21 expression (93.7\%), and significant loss of p21 expression was observed in cancers with high pT stages $\left(\mathrm{pT}_{3}\right.$ and $\left.\mathrm{pT}_{4} ; \mathrm{p}=0.011\right)$, lymph node metastasis $(\mathrm{p}=0.029)$ and advanced cancer stage defined by the American Joint Committee on Cancer $(p=0.005)$. Overexpression of p53 was
\end{abstract}

\section{KARGER}

Fax +41613061234 E-Mail karger@karger.ch www.karger.com

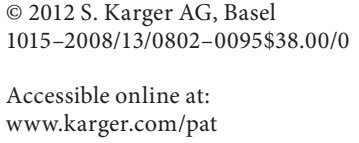

found in $23.4 \%$ of cases. Positive expression of p53 was associated with distally located SIACs (jejunum or ileum; $p=$ 0.006). There was no association between the expression of S100A14 and p21 or p53. Conclusion: Loss of S100A14 in SIAC is common and is associated with higher metastatic potential and advanced clinical stage.

Copyright $\odot 2012$ S. Karger AG, Basel

\section{Introduction}

Small intestinal adenocarcinoma (SIAC) is an exceedingly rare tumor even though the small intestine occupies about $90 \%$ of the absorptive surface area of the human gastrointestinal tract [1]. It comprises $<5 \%$ of whole gastrointestinal tract tumors $[2,3]$. Despite recent advances in the techniques used to approach the small intestine [4], the early detection of SIAC is quite challenging [5]. Due to its rarity, the molecular carcinogenesis of SIAC is still poorly understood [5-7].

S100A14 is one of the least-known subtypes of the 20 S100 family members and was only recently identified on 
chromosome 1q21 [8, 9]. S100A14 mRNA has been reported to be expressed in several normal human tissues, including the colon, and the functional role of S100A14 in malignant tumors is organ specific. Loss of S100A14 expression has been reported in tumors of the kidney, esophagus and colorectum, while overexpression of S100A14 has been reported in several cancers, including cancers of the ovary, urinary bladder, breast and uterus $[8,10-13]$. A recent study has reported that the low expression of S100A14 is associated with a high metastatic potential and poor prognostic outcome in patients with colorectal cancer [14]. S100A14 induces cell cycle arrest or apoptosis in oral and esophageal squamous cell carcinomas $[10,15,16]$, and regulates the cell cycle in a p53- or receptor for advanced glycation end-products (RAGE)dependent manner. However, there are no published studies on S100A14 expression in SIAC. To identify the role of S100A14 in SIAC, we investigated the expression of S100A14, p21 and p53 in these tumors using immunohistochemistry.

\section{Materials and Methods}

\section{Patients and Specimens}

One hundred and ninety-seven surgically resected SIACs were collected from 22 institutions in Korea. Representative hematoxylin and eosin slides, paraffin tissue blocks and the appropriate approvals from the institutional review board of each institution that participated in the Korean Small Intestinal Cancer Study Group were obtained. Primary carcinomas arising from the duodenum, jejunum and ileum were included in this study. Malignant tumors from other gastrointestinal tract organs, such as the stomach, ampulla of Vater, pancreas or appendix with extension to the small intestine, were excluded. Data were collected by reviewing the medical records of the patients, including each patient's sex, age, other accompanying tumors, results of the most recent follow-up examination and survival status. The pathological characteristics that were evaluated included growth patterns, tumor location, tumor size, histological subtype, differentiation status, depth of invasion, lymph node metastases and the presence of lymphatic invasion.

\section{Tissue Microarray}

In order to construct the tissue microarrays of the 197 cases, tissue cores that were $2 \mathrm{~mm}$ in diameter were obtained from morphologically representative areas of the formalin-fixed paraffinembedded blocks after being reviewed by two experienced gastrointestinal tract pathologists (G.K. and S.-M.H.). Areas where tumor cells occupied $>75 \%$ of cells with major histological differentiation and without accompanying tumor necrosis were selected. The tissue array blocks consisted of 2 or 3 cores from each tumor tissue, 1 core from a corresponding metastatic lymph node and 1 core from a matched normal tissue.
Immunohistochemistry and Interpretation

Serial $4-\mu \mathrm{m}$ sections were applied to 3-aminopropyltriethoxysilane-coated slides (Sigma, St. Louis, Mo., USA). Deparaffinization and rehydration were performed using xylene and alcohol. Endogenous peroxidase was blocked using a 3\% solution of aqueous hydrogen peroxide. The slides were pretreated with citrate buffer ( $\mathrm{pH}$ 6.0) in a microwave oven for antigen retrieval. The sections were incubated at room temperature for $60 \mathrm{~min}$ with mouse monoclonal anti-S100A14 (1:200; Santa Cruz Biotechnology, Santa Cruz, Calif., USA), mouse monoclonal anti-p21 (4D10, 1:100; Novocastra, Newcastle, UK) and mouse monoclonal antip53 (DO-7, 1:100; Novocastra). The sections were reacted with peroxidase-conjugated streptavidin for $30 \mathrm{~min}$. Diaminobenzidine was used as the chromogen, and the sections were counterstained with hematoxylin. Immunohistochemical staining was successfully performed on 175 of 197 SIACs on the tissue microarrays. Because several tissue cores were lost during sectioning or the staining process, they were not successfully immunolabeled. Both the percentage of positive tumor cells and the intensity of the positive staining were graded.

An intensity scale was categorized from 0 to 3 as follows; 0 , corresponding to no labeling of neoplastic epithelial cells; 1 , corresponding to weak labeling of neoplastic epithelium which could best seen at $10 \times$ objective; 2 , corresponding to unequivocal labeling of epithelial cells, and 3, corresponding to intense labeling, which was previously described elsewhere [17]. Loss of S100A14 expression was defined as positive immunostaining in $<30 \%$ of the tumor cells, as previously described [14]. Sections were considered positive for $\mathrm{p} 21$ and $\mathrm{p} 53$ when $\geq 10 \%$ of the tumor cell nuclei were stained [18].

\section{Statistical Analysis}

In order to compare any associations between the immunohistochemical markers and clinicopathological parameters, the $\chi^{2}$ and Fisher exact tests were performed. Overall patient survival was defined as the time from surgical resection of the SIAC to death of the patient or last follow-up examination. The survival rate was calculated using the Kaplan-Meier method. Comparisons of the survival rates and associations with the various clinicopathological factors were performed using the log-rank test. Statistical analyses were performed using IBM SPSS 19.0 software (SPSS, Chicago, Ill., USA). A p value $<0.05$ was considered statistically significant.

\section{Results}

\section{Clinical and Pathological Characteristics}

The study group consisted of 175 cases (111 men and 64 females) with a mean age of 58.1 years (rage: $23-86$ years). Fifteen cases were in stage $0-I, 70$ were in stage II and 90 were in stage III (table 1). There were 103 duodenal carcinomas and 72 jejunal/ileal tumors. The case numbers in each clinical stage were 0-I, 10 (9.7\%); II, 40 (38.8\%), and III, 53 (51.5\%) in duodenal carcinomas, and 0-I, 5 (6.9\%); II, 30 (41.7\%), and III, 37 (51.4\%) in jejunal/ ileal tumors. However, there was no significant difference in clinical stages between the two groups $(\mathrm{p}=0.79)$. 
Association between the Loss of S100A14 Expression and Clinicopathological Factors in Primary SIAC

S100A14 expression was observed on the cellular membrane of normal small intestinal mucosal epithelial cells (fig. 1a). Surface epithelial cells expressed S100A14 most strongly. S100A14 expression decreased in the crypts and disappeared in Brunner's glands. Of 175 SIACs, loss of S100A14 expression was observed in the majority of cases $(128,73.1 \%$; fig. 1b, c). Loss of S100A14 expression was demonstrated in 4 of 8 accompanying adenoma cases (50\%; data not shown). Loss of S100A14 expression was more commonly observed in ulceroinfiltrative (103 of $133,77.4 \%$ ) or polypoid tumors ( 21 of 31 , $67.7 \%$ ) than flat tumors ( 4 of $11,34.6 \% ; p=0.012$; fig. $1 d$ ). Loss of S100A14 expression was more frequently observed in distal (jejunum or ileum) tumors (59 of 72 , $81.9 \%$ ) than proximal (duodenum) tumors (69 of 103, $67 \% ; \mathrm{p}=0.043$ ). Cases with lymph node metastasis ( 74 of 90, 82.2\%) demonstrated increased loss of S100A14 expression compared with cases without lymph node metastasis ( 54 of $85,63.5 \%$; $\mathrm{p}=0.009$ ). The proportion of cases with loss of S100A14 expression significantly increased with increasing American Joint Committee on Cancer (AJCC) cancer staging (stage $0-\mathrm{I}, 8$ of 15, 53.3\%; stage II, 46 of $70,65.7 \%$; stage III, 74 of $90,82.2 \%$; $\mathrm{p}=$ 0.013 ; table 1). There was no association between loss of S100A14 expression and the other clinicopathological factors.

\section{Expression of $p 21$ and $p 53$}

Because some previous studies have reported that the functional role of S100A14 in cell cycle arrest is regulated by $\mathrm{p} 21$ and $\mathrm{p} 53[10,15]$, we used immunohistochemical analysis to study p21 and p53. Both p21 and p53 are located in the nuclei of cancer cells (fig. 2). The associations between the protein expression levels of p 21 and p53 and the examined clinicopathological factors are summarized in table 2. Of 175 SIAC cases, 164 cases demonstrated loss of p21 expression (93.7\%). We found that SIACs that demonstrated the loss of $\mathrm{p} 21$ expression were more likely to invade into lymphovascular spaces $(\mathrm{p}=$ 0.031). Significant loss of $\mathrm{p} 21$ expression was more frequently observed in high $\mathrm{pT}$ cancers $\left(\mathrm{pT}_{3}-\mathrm{pT}_{4}, 152\right.$ of 159 cases, $95.6 \%)$ than in low $\mathrm{pT}$ tumors $\left(\mathrm{pT}_{\mathrm{is}}-\mathrm{pT}_{2}, 12\right.$ of 16 cases, $75 \%$; $\mathrm{p}=0.011$ ), in carcinomas with lymph node metastasis $\left(\mathrm{pN}_{1}+\mathrm{pN}_{2}, 88\right.$ of $\left.90,97.8 \%\right)$ than those without lymph node metastasis $\left(\mathrm{pN}_{0}, 76\right.$ of $85,89.4 \%$; $\mathrm{p}=$ 0.029 ) and advanced-stage cancers (stage $0-\mathrm{I}, 11$ of 15 , $73.3 \%$; stage II, 65 of $70,92.2 \%$; stage III, 88 of $90,97.8 \%$; $\mathrm{p}=0.005)$. Aberrant $\mathrm{p} 53$ protein expression was ob-
Table 1. Correlation between S100A14 expression and clinicopathological characteristics of SIACs

\begin{tabular}{|c|c|c|c|c|}
\hline \multirow[t]{2}{*}{$\begin{array}{l}\text { Clinicopathological } \\
\text { information }\end{array}$} & \multirow[t]{2}{*}{$\mathrm{n}$} & \multicolumn{2}{|c|}{$\begin{array}{l}\text { S100A14 } \\
\text { expression, n (\%) }\end{array}$} & \multirow[t]{2}{*}{$\begin{array}{l}\mathrm{p} \\
\text { value }\end{array}$} \\
\hline & & loss & intact & \\
\hline Sex & & & & 0.642 \\
\hline Male & 111 & $83(74.8)$ & $28(25.2)$ & \\
\hline Female & 64 & $45(70.3)$ & $19(29.7)$ & \\
\hline Age & & & & 0.482 \\
\hline$<60$ years & 91 & $64(70.3)$ & $27(29.7)$ & \\
\hline$\geq 60$ years & 84 & $64(76.2)$ & $20(23.8)$ & \\
\hline Type of growth & & & & $0.012^{\mathrm{a}}$ \\
\hline Polypoid & 31 & $21(67.7)$ & $10(32.3)$ & \\
\hline Flat & 11 & $4(36.4)$ & $7(63.6)$ & \\
\hline Ulceroinfiltrative & 133 & $103(77.4)$ & $30(22.6)$ & \\
\hline Location & & & & 0.043 \\
\hline Duodenum & 103 & $69(67)$ & $34(33)$ & \\
\hline Jejunum + ileum & 72 & $59(81.9)$ & $13(18.1)$ & \\
\hline Histological subtype & & & & $0.491^{\mathrm{a}}$ \\
\hline Adenocarcinoma & 159 & $114(71.7)$ & $45(28.3)$ & \\
\hline Mucinous carcinoma & 9 & $8(88.9)$ & $1(11.1)$ & \\
\hline Signet ring cell & & & & \\
\hline carcinoma & 4 & $3(75)$ & $1(25)$ & \\
\hline Undifferentiated & & & & \\
\hline carcinoma & 3 & $3(100)$ & $0(0)$ & \\
\hline Differentiation & & & & 0.362 \\
\hline Well/moderate & 135 & $96(71.1)$ & $39(28.9)$ & \\
\hline Poor/undifferentiated & 40 & $32(80)$ & $8(20)$ & \\
\hline Lymphovascular invasion & & & & 0.412 \\
\hline Absent & 86 & $60(69.8)$ & $26(30.2)$ & \\
\hline Present & 89 & $68(76.4)$ & $21(23.6)$ & \\
\hline T classification & & & & 0.192 \\
\hline $\mathrm{pT}_{\mathrm{is}}-\mathrm{pT}_{2}$ & 16 & $9(56.3)$ & $7(43.8)$ & \\
\hline $\mathrm{pT}_{3}+\mathrm{pT}_{4}$ & 159 & $119(74.8)$ & $40(25.2)$ & \\
\hline $\mathrm{N}$ classification & & & & 0.009 \\
\hline $\mathrm{pN}_{0}$ & 85 & $54(63.5)$ & $31(36.5)$ & \\
\hline $\mathrm{pN}_{1}+\mathrm{pN}_{2}$ & 90 & $74(82.2)$ & $16(17.8)$ & \\
\hline AJCC staging & & & & 0.013 \\
\hline $0-\mathrm{I}$ & 15 & $8(53.3)$ & $7(46.7)$ & \\
\hline II & 70 & $46(65.7)$ & $24(34.3)$ & \\
\hline III & 90 & $74(82.2)$ & $16(17.8)$ & \\
\hline Total & 175 & $128(73.1)$ & $47(26.9)$ & \\
\hline
\end{tabular}

Significant differences are highlighted in bold.

${ }^{a} \mathrm{p}$ value determined using the Fisher exact test.

served in 41 of 175 SIAC cases (23.4\%). Abnormal p53 expression was more commonly noted in distally located SIACs ( 25 of 72 cases, $34.7 \% ; \mathrm{p}=0.006$; table 2 ). There was no correlation between the expression of S100A10 and p 21 or p53 (table 3). 
Fig. 1. Representative images of S100A14 labeling of normal small intestinal mucosa and SIAC. a S100A14 labeling on the cell membrane of normal small intestinal epithelial cells. b, c Moderately and poorly differentiated SIAC cells expressing S100A14. d SIAC demonstrating the loss of S100A14.

Fig. 2. Representative images of nuclear p21 and p53 immunolabeling of SIAC.
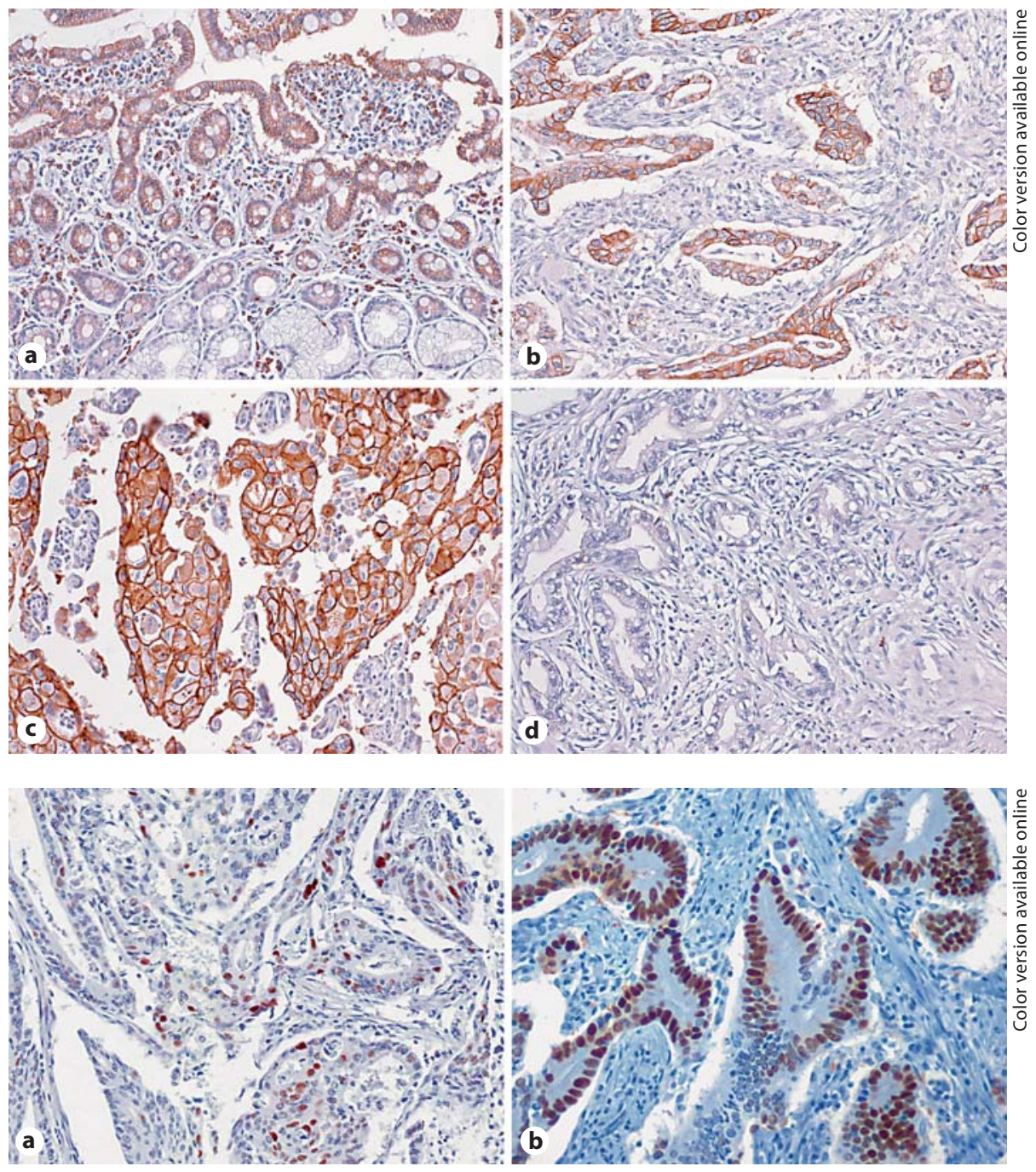

Correlation between S100A14 Expression and Clinical Outcomes

The median survival time of the patients that demonstrated loss of S100A14 expression was 30 months, while patients with intact S100A14 expression showed a median survival time of 47.6 months; however, there was no significant survival difference between patients with loss of S100A14 expression and those with intact S100A14 expression ( $\mathrm{p}=0.619$; fig. 3 ).

\section{Discussion}

The S100 family consists of calcium-modulated EFhand-type proteins with intra- and extracellular functions. The functions of some of the S100 subfamily mem- bers, such as the role of S100A4 in metastasis, are well characterized [19]. However, because S100A14 was just recently characterized using a small cell lung carcinoma cell line, its function in human tumors is largely unknown $[8,20]$. We previously reported that distal SIACs demonstrate more $\mathrm{pT}_{4}$ tumors, and that patients with distal SIACs demonstrate a significantly shorter median survival than patients with proximal (duodenal) cancers [21]. In the present study, we found that the loss of S100A14 expression is associated with distally located SIACs, and this result indirectly implies a possible correlation between loss of S100A14 expression and a poor prognostic outcome.

Regarding cancers of the gastrointestinal tract, only a recent study that used human colorectal cancer tissues has ever reported the clinical significance of S100A14 ex- 
Table 2. Correlation between $\mathrm{p} 21$ and $\mathrm{p} 53$ expression and the clinicopathological characteristics of SIACs

\begin{tabular}{|c|c|c|c|c|c|c|c|}
\hline \multirow{2}{*}{$\begin{array}{l}\text { Clinicopathological } \\
\text { information }\end{array}$} & \multirow[t]{2}{*}{$\mathrm{n}$} & \multicolumn{2}{|c|}{$\mathrm{p} 21, \mathrm{n}(\%)$} & \multirow{2}{*}{$\begin{array}{l}\mathrm{p} \\
\text { value }\end{array}$} & \multicolumn{2}{|l|}{ p53, n (\%) } & \multirow{2}{*}{$\begin{array}{l}\mathrm{p} \\
\text { value }\end{array}$} \\
\hline & & negative & positive & & negative & positive & \\
\hline Location & & & & $0.529^{\mathrm{a}}$ & & & 0.006 \\
\hline Duodenum & 103 & $95(92.2)$ & $8(7.8)$ & & $87(84.5)$ & $16(15.5)$ & \\
\hline Jejunum + ileum & 72 & $69(95.8)$ & $3(4.2)$ & & $47(65.3)$ & $25(34.7)$ & \\
\hline Lymphovascular invasion & & & & $0.031^{\mathrm{a}}$ & & & 0.097 \\
\hline Absent & 86 & $77(89.5)$ & $9(10.5)$ & & $71(82.6)$ & $15(17.4)$ & \\
\hline Present & 89 & $87(97.8)$ & $2(2.2)$ & & $63(70.8)$ & $26(29.2)$ & \\
\hline T classification & & & & $0.011^{\mathrm{a}}$ & & & $0.766^{\mathrm{a}}$ \\
\hline $\mathrm{pT}_{\mathrm{is}}-\mathrm{pT}_{2}$ & 16 & $12(75.0)$ & $4(25.0)$ & & $13(81.3)$ & $3(18.8)$ & \\
\hline $\mathrm{pT}_{3}-\mathrm{pT}_{4}$ & 159 & $152(95.6)$ & $7(4.4)$ & & $121(76.1)$ & $38(23.9)$ & \\
\hline $\mathrm{N}$ classification & & & & $0.029^{a}$ & & & 0.614 \\
\hline $\mathrm{pN}_{0}$ & 85 & $76(89.4)$ & $9(10.6)$ & & $67(78.8)$ & $18(21.1)$ & \\
\hline $\mathrm{pN}_{1}-\mathrm{pN}_{2}$ & 90 & $88(97.8)$ & $2(2.2)$ & & $67(74.4)$ & $23(25.6)$ & \\
\hline AJCC staging & & & & $0.005^{\mathrm{a}}$ & & & $0.641^{\mathrm{a}}$ \\
\hline $0-\mathrm{I}$ & 15 & $11(73.3)$ & $4(26.7)$ & & $13(86.7)$ & $2(13.3)$ & \\
\hline II & 70 & 65 (92.9) & $5(7.1)$ & & $54(77.7)$ & $16(22.9)$ & \\
\hline III & 90 & $88(97.8)$ & $2(2.2)$ & & $67(74.4)$ & $23(25.6)$ & \\
\hline Total & 175 & $164(93.7)$ & $11(6.3)$ & & $134(76.6)$ & $41(23.4)$ & \\
\hline
\end{tabular}

Significant differences are highlighted in bold. ${ }^{a}$ p value determined using the Fisher exact test.

Table 3. Associations between the expression levels of S100A14, p21 and p53 in SIACs

\begin{tabular}{|c|c|c|c|c|c|c|c|}
\hline \multirow{2}{*}{$\begin{array}{l}\text { Immunohistochemical } \\
\text { markers }\end{array}$} & \multirow[t]{2}{*}{$\mathrm{n}$} & \multicolumn{2}{|l|}{ p21, n (\%) } & \multirow{2}{*}{$\begin{array}{l}\mathrm{p} \\
\text { value }\end{array}$} & \multicolumn{2}{|l|}{ p53, n (\%) } & \multirow{2}{*}{$\begin{array}{l}\mathrm{p} \\
\text { value }\end{array}$} \\
\hline & & negative & positive & & negative & positive & \\
\hline S100A14 & & & & $0.277^{\mathrm{a}}$ & & & 0.837 \\
\hline Negative & 128 & $122(95.3)$ & $6(4.7)$ & & $97(75.8)$ & $31(24.2)$ & \\
\hline Positive & 47 & $42(89.4)$ & $5(10.6)$ & & $37(78.7)$ & $10(21.3)$ & \\
\hline Total & 175 & 164 & 11 & & 134 & 41 & \\
\hline
\end{tabular}

a The Fisher exact test was employed to determine significant differences.

pression. Low S100A14 expression is associated not only with a high metastatic potential but also with a poor prognostic outcome in patients with colorectal carcinomas [14]. Although we did not find a prognostic association with S100A14 expression in SIACs, our results show that the loss of S100A14 expression is correlated with the presence of lymph node metastasis and high AJCC staging in SIACs, which are concordant with the results of a previous study on colorectal cancers. The discrepancy of the correlation between lymph node metastasis and prognostic outcome could be explained by several possible reasons, such as lack of distant metastasis in our cases, no association between loss of S100A14 expression and tumoral stages, and other unknown molecular interactions. Taken together, S100A14 may work as a potential tumor suppressor of SIACs.

The molecular pathogenesis of S100A14 and its association with tumor progression has been studied only in a limited number of malignant tumors. S100A14 regulates the expression of MMP1, MMP9, p21 and p53 in oral squamous cell carcinomas [15, 22]. For example, S100A14 represses the proliferation of oral squamous carcinoma cell lines with wild-type $\mathrm{p} 53$ by inducing $\mathrm{G} 1$ arrest in association with the upregulation of p21 [15]. In esophageal 


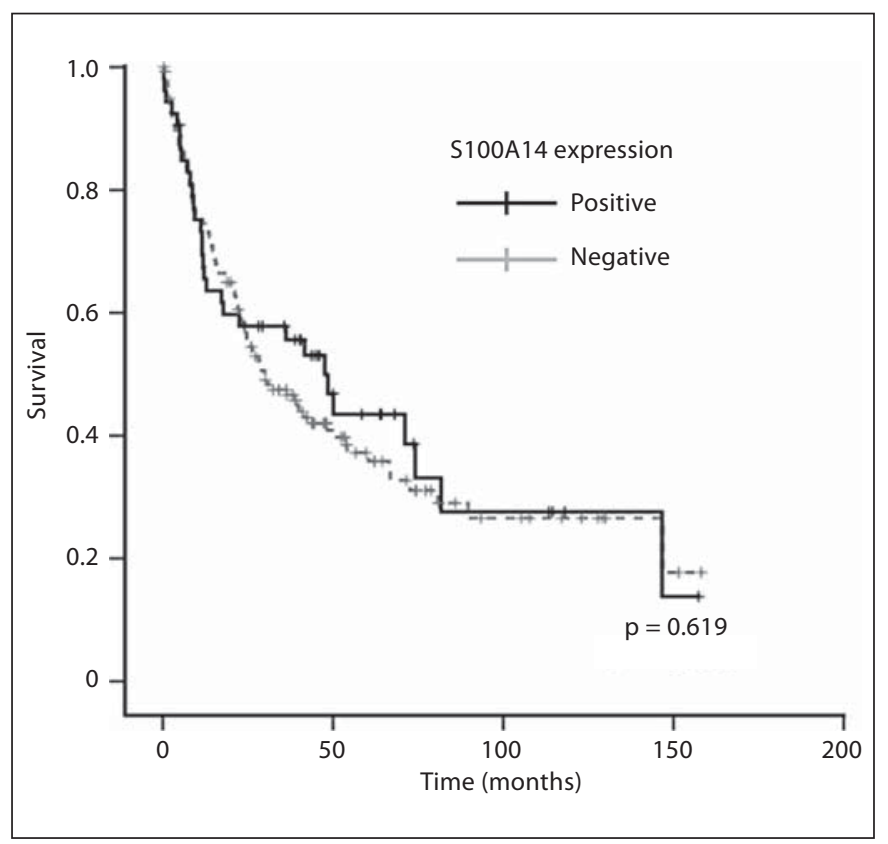

Fig. 3. Kaplan-Meier survival analysis of SIACs according to S100A14 expression status. The median survival time of the patients who demonstrated loss of S100A14 expression was 30 months, while patients with intact S100A14 expression demonstrated a median survival time of 47.6 months. There was no statistically significant survival difference between cases that demonstrated a loss of S100A14 expression and cases with intact S100A14 expression $(\mathrm{p}=0.619)$.

squamous cell carcinomas, S100A14 is involved in RAGE and $\mathrm{p} 53$ pathways $[10,16]$. In particular, cancer cells with down-regulated S100A14 expression can escape apoptotic mechanisms that are regulated by $\mathrm{p} 21$ or $\mathrm{p} 53$. However, in the present study, we did not observe any association between S100A14 and p21 or p53 expression in SIACs. Even if S100A14 is downregulated in both esophageal carcinomas and SIACs, the role S100A14 plays in tumor progression or metastasis may be different. In addition, because the loss of p21 expression was correlated not only with higher $\mathrm{pT}$ and $\mathrm{pN}$ classifications but also AJCC staging, the expression of $\mathrm{p} 21$ could be a possible prognostic indicator of SIAC regardless of S100A14 expression. On the contrary, p53 expression did not demonstrate any clinical significance in SIAC. Although a single study on p21 expression in SIACs was previously reported, its clinical implications have not been revealed yet. The expression of p21 was found to be decreased in SIACs (46\%) in comparison with small intestinal adenomas (50\%) in the previous study [18]. In addition, the overexpression of p53 in SIACs has been reported to vary between 24 and 65\%.
Little is known about the clinical significance of $\mathrm{p} 53$ overexpression in SIACs either [18, 23, 24].

The upregulation of S100A14 has been reported to occur predominantly in basal-like breast carcinoma, which is considered both a stem cell phenotype and a type of circulating breast cancer cell $[11,25]$. This result implies the possibility that S100A14 expression could be associated with the cancer stem cell phenotype. This may suggest different levels of S100A14 expression depending on the organ. Further research on the role of S100A14 in cancer stem cells and SIAC is warranted.

In conclusion, loss of S100A14 expression was observed in a major subset of SIACs and associated with lymph node metastasis and advanced clinical stage. These findings suggest that $\mathrm{S} 100 \mathrm{~A} 14$ plays a role as a tumor suppressor in SIACs. To the best of our knowledge, this is the first report on the expression of S100A14 in SIACs.

\section{Acknowledgments}

This research was supported by the Basic Science Research Program through the National Research Foundation of Korea and funded by the Ministry of Education, Science and Technology (2010-0004807). We would like to thank the members of the Korean Small Intestinal Cancer Study Group: Dr. Hee-Kyung Chang, Kosin University College of Medicine, Pusan; Dr. Eun Sun Jung, Catholic University of Korea College of Medicine, Seoul; Drs. Ghil Suk Yoon and Han-Ik Bae, Kyungpook National University, Dague; Dr. Joon Mee Kim, Inha University College of Medicine, Incheon; Dr. Young-Ha Oh, Hanyang University College of Medicine, Seoul; Dr. Soo Jin Jung, Inje University College of Medicine, Busan; Dr. Mi Jin Gu, Fatima Hospital, Daegu; Dr. Jung Yeon Kim, Inje University Sanggye Paik Hospital, Seoul; Dr. Kyu Yun Jang, Chonbuk National University Medical School, Jeonju; Dr. Kye Won Kwon, Bundang Jesaeng General Hospital, Seongnam; Dr. Gyeong Hoon Kang, Seoul National University College of Medicine, Seoul; Dr. Jae Bok Park, Catholic University of Daegu, Daegu; Dr. Soon Won Hong, Yonsei University College of Medicine, Seoul, and Dr. Ji Shin Lee, Chonnam National University Medical School, Gwangju, South Korea.

References FD: The epidemiology and pathogenesis of neoplasia in the small intestine. Ann Epidemiol 2009; 19:58-69.

-2 Jemal A, Siegel R, Ward E, Hao Y, Xu J, Murray T, Thun MJ: Cancer statistics, 2008. CA Cancer J Clin 2008;58:71-96.

- 3 Warth A, Kloor M, Schirmacher P, Blaker H: Genetics and epigenetics of small bowel adenocarcinoma: the interactions of CIN, MSI, and CIMP. Mod Pathol 2011;24:564-570. 
4 Rondonotti E, Pennazio M, Toth E, Menchen P, Riccioni ME, De Palma GD, Scotto F, De Looze D, Pachofsky T, Tacheci I, Havelund T, Couto G, Trifan A, Kofokotsios A, Cannizzaro R, Perez-Quadrado E, de Franchis R, European Capsule Endoscopy Group, Italian Club for Capsule Endoscopy (CICE), Iberian Group for Capsule Endoscopy: Small-bowel neoplasms in patients undergoing video capsule endoscopy: a multicenter European study. Endoscopy 2008;40:488-495.

$\checkmark 5$ Zouhairi ME, Venner A, Charabaty A, Pishvaian MJ: Small bowel adenocarcinoma. Curr Treat Options Oncol 2008;9:388-399.

-6 Overman MJ, Pozadzides J, Kopetz S, Wen S, Abbruzzese JL, Wolff RA, Wang H: Immunophenotype and molecular characterisation of adenocarcinoma of the small intestine. Br J Cancer 2010;102:144-150.

$>7$ Delaunoit T, Neczyporenko F, Limburg PJ, Erlichman C: Pathogenesis and risk factors of small bowel adenocarcinoma: a colorectal cancer sibling? Am J Gastroenterol 2005; 100:703-710.

8 Pietas A, Schluns K, Marenholz I, Schafer BW, Heizmann CW, Petersen I: Molecular cloning and characterization of the human S100A14 gene encoding a novel member of the S100 family. Genomics 2002;79:513-522.

$\checkmark 9$ Adam PJ, Boyd R, Tyson KL, Fletcher GC, Stamps A, Hudson L, Poyser HR, Redpath N, Griffiths M, Steers G, Harris AL, Patel S, Berry J, Loader JA, Townsend RR, Daviet L, Legrain P, Parekh R, Terrett JA: Comprehensive proteomic analysis of breast cancer cell membranes reveals unique proteins with potential roles in clinical cancer. J Biol Chem 2003;278:6482-6489.

-10 Chen H, Yu D, Luo A, Tan W, Zhang C, Zhao D, Yang M, Liu J, Lin D, Liu Z: Functional role of S100A14 genetic variants and their association with esophageal squamous cell carcinoma. Cancer Res 2009;69:3451-3457.
11 McKiernan E, McDermott EW, Evoy D, Crown J, Duffy MJ: The role of S100 genes in breast cancer progression. Tumour Biol 2011; 32:441-450.

12 Ji J, Zhao L, Wang X, Zhou C, Ding F, Su L, Zhang C, Mao X, Wu M, Liu Z: Differential expression of $\mathrm{S} 100$ gene family in human esophageal squamous cell carcinoma. J Cancer Res Clin Oncol 2004;130:480-486.

$>13$ Yao R, Lopez-Beltran A, Maclennan GT, Montironi R, Eble JN, Cheng L: Expression of $\mathrm{S} 100$ protein family members in the pathogenesis of bladder tumors. Anticancer Res 2007;27:3051-3058.

14 Wang HY, Zhang JY, Cui JT, Tan XH, Li WM, Gu J, Lu YY: Expression status of S100A14 and S100A4 correlates with metastatic potential and clinical outcome in colorectal cancer after surgery. Oncol Rep 2010;23:45-52.

15 Sapkota D, Costea DE, Blo M, Bruland O, Lorens JB, Vasstrand EN, Ibrahim SO: S100A14 inhibits proliferation of oral carcinoma derived cells through G1-arrest. Oral Oncol 2012;48:219-225

16 Jin Q, Chen H, Luo A, Ding F, Liu Z: S100A14 stimulates cell proliferation and induces cell apoptosis at different concentrations via receptor for advanced glycation end products (RAGE). PLoS One 2011;6:e19375.

17 Winter JM, Ting AH, Vilardell F, Gallmeier E, Baylin SB, Hruban RH, Kern SE, Iacobuzio-Donahue CA: Absence of E-cadherin expression distinguishes noncohesive from cohesive pancreatic cancer. Clin Cancer Res 2008;14:412-418.

-18 Arber N, Hibshoosh H, Yasui W, Neugut AI, Hibshoosh A, Yao Y, Sgambato A, Yamamoto H, Shapira I, Rosenman D, Fabian I, Weinstein IB, Tahara E, Holt PR: Abnormalities in the expression of cell cycle-related proteins in tumors of the small bowel. Cancer Epidemiol Biomarkers Prev 1999;8:1101-1105.
19 Salama I, Malone PS, Mihaimeed F, Jones JL: A review of the $S 100$ proteins in cancer. Eur J Surg Oncol 2008;34:357-364.

20 Donato R: S100: a multigenic family of calcium-modulated proteins of the ef-hand type with intracellular and extracellular functional roles. Int J Biochem Cell Biol 2001;33: 637-668.

-21 Chang HK, Yu E, Kim J, Bae YK, Jang KT, Jung ES, Yoon GS, Kim JM, Oh YH, Bae HI, Kim GI, Jung SJ, Gu MJ, Kim JY, Jang KY, Jun SY, Eom DW, Kwon KW, Kang GH, Park JB, Hong S, Lee JS, Park JY, Hong SM: Adenocarcinoma of the small intestine: a multi-institutional study of 197 surgically resected cases. Hum Pathol 2010;41:1087-1096.

$>22$ Sapkota D, Bruland O, Costea DE, Haugen $\mathrm{H}$, Vasstrand EN, Ibrahim SO: S100A14 regulates the invasive potential of oral squamous cell carcinoma derived cell-lines in vitro by modulating expression of matrix metalloproteinases, MMP1 and MMP9. Eur J Cancer 2011;47:600-610.

23 Wheeler JM, Warren BF, Mortensen NJ, Kim HC, Biddolph SC, Elia G, Beck NE, Williams GT, Shepherd NA, Bateman AC, Bodmer WF: An insight into the genetic pathway of adenocarcinoma of the small intestine. Gut 2002;50:218-223.

-24 Svrcek M, Jourdan F, Sebbagh N, Couvelard A, Chatelain D, Mourra N, Olschwang S, Wendum D, Flejou JF: Immunohistochemical analysis of adenocarcinoma of the small intestine: a tissue microarray study. J Clin Pathol 2003;56:898-903.

-25 Smirnov DA, Zweitzig DR, Foulk BW, Miller MC, Doyle GV, Pienta KJ, Meropol NJ, Weiner LM, Cohen SJ, Moreno JG, Connelly MC, Terstappen LW, O'Hara SM: Global gene expression profiling of circulating tumor cells. Cancer Res 2005;65:4993-4997. 